\title{
APARAT REPRESJI WOBEC KOŚCIOLA KATOLICKIEGO METROPOLII LWOWSKIEJ OBRZĄDKU LACIŃSKIEGO W LATACH 1939-1950 - STAN BADAŃ
}

Stosunkowo krótki etap historii Kościoła katolickiego, obejmujący lata 1939-1950, należał do szczególnie dramatycznych w dziejach Kościoła w Polsce. W szczególny sposób doświadczyła go metropolia lwowska ob. łac. Należały do niej: archidiecezja lwowska, diecezja przemyska i diecezja łucka. W 1939 r. archidiecezja lwowska liczyła 1.079.108 wiernych obrządku łac. czyli ludności polskiej. Dzieliła się na 28 dekanatów, 416 parafii. W duszpasterstwie, którym kierował abp Bolesław Twardowski zaangażowanych było 487 księży diecezjalnych i 87 zakonnych $^{1}$. Diecezja przemyska w 1938 r. liczyła 1.119 .822 wiernych obrządku łac., czyli ludności polskiej, ponadto 800.000 wiernych obrządku greckokatolickiego, 7752 akatolików i 184.965 Żydów. Dzieliła się na 35 dekanatów liczących 351 parafii. W duszpasterstwie, którym kierował bp Franciszek Barda zaangażowanych było 731 księży diecezjalnych i 136 zakonnych $^{2}$. W diecezji funkcjonowały 33 klasztory męskie oraz 184 żeńskie z 1250 siostrami $^{3}$. Diecezja łucka w 1939 r. liczyła około 320.000 wiernych obrządku łac., czyli ludności polskiej. Dzieliła się na 12 dekanatów, 122 parafie. W duszpasterstwie, którym kierował bp Adolf Szelążek zaangażowanych było 240 księży obrządku rzymskokatolickiego ${ }^{4}$.

* Ks. Józef Szymański - dr historii Kościoła, adiunkt w Instytucie Badań nad Polonią i Duszpasterstwem Polonijnym KUL.

1 W. Urban, Archidiecezja lwowska, w: Życie religijne w Polsce pod okupacja 1939-1945. Metropolie wileńska i lwowska, zakony, red. Z. Zieliński, Katowice 1992, s. 91-171.

${ }^{2}$ T. Śliwa, Diecezja przemyska, w: Życie religijne w Polsce pod okupacja 1939-1945. Metropolie wileńska i lwowska, zakony, red. Z. Zieliński, Katowice 1992, s. 172-199.

${ }^{3}$ H. Borcz, Archidiecezja przemyska - zarys dziejów, w: Rocznik Archidiecezji Przemyskiej 1997. Album, Przemyśl 1997, s. 14.

${ }^{4}$ G. Hryciuk, Przemiany narodowościowe i ludnościowe w Galicji Wschodniej i na Wolyniu w latach 1931-1948, Toruń 2005, s. 49; Por. L. Popek, Diecezja tucka, w: Życie religijne w Polsce pod okupacja 1939-1945. Metropolie wileńska i lwowska, zakony, red. Z. Zieliński, Katowice 1992, 
Po klęsce militarnej Polski we wrześniu 1939 r. terytorium metropolii, zwłaszcza diecezji przemyskiej, uległo podziałowi pomiędzy dwóch agresorów. Granica pomiędzy ziemiami okupowanymi przez Niemcy i Związek Sowiecki przebiegała mniej więcej wzdłuż rzeki $\mathrm{San}^{5}$. W zaistniałej sytuacji w niemieckiej strefie okupacyjnej liczącej ok. 900000 wiernych rezydował bp ordynariusz przemyski Franciszek Barda ${ }^{6}$, zaś w sowieckiej (ok. 200000 wiernych) bp pomocniczy Wojciech Tomaka. Po wybuchu wojny niemiecko-sowieckiej (22 VI 1941) cała diecezja znalazła się pod okupacją hitlerowską (do VII 1944/I 1945) i jej terytorium zostało wcielone do Generalnej Guberni ${ }^{7}$.

Granica na Sanie podzieliła również stolicę diecezji - Przemyśl. 4 XII 1939 r. prawobrzeżna część miasta z katedrą, siedzibą biskupa i seminarium znalazła się w granicach obłasti drohobyckiej ${ }^{8}$. Lewobrzeżna część Przemyśla - tzw. Zasanie otrzymało 26 X niemiecki cywilny zarząd okupacyjny. Ta część Przemyśla (licząca $7 \mathrm{~km}^{2}$ ) straciła prawa odrębnej jednostki administracyjnej wchodząc w skład powiatu jarosławskiego. Jednak już 27 VI 1940 r. H. Frank wydał zarządzenie na mocy którego z Zasania utworzono odrębną jednostkę administracyjną DeutschPrzemyśl, która po rozszerzeniu granic na okoliczne wioski została podniesiona do rangi starostwa miejskiego.

Po klęsce wrześniowej i wkroczeniu na tereny metropolii lwowskiej Armii Czerwonej ujawniły się animozje polsko-ukraińskie. Ukraińcy zdecydowali się na wrogie wystapienia przeciwko państwu polskiemu i polskości. Wystapienia przybierały postać: mordów, bicia, poniżania, rabunku mienia, zatrzymywania i denuncjacji wobec wojsk radzieckich, co zazwyczaj kończyło się aresztowaniem, wywózką a niejednokrotnie i śmiercią ${ }^{9}$ Dekretem Rady Najwyższej ZSRR z 29 listopada 1939 r. nadano wszystkim obywatelom polskim, przymusowo, bez względu na narodowość - obywatelstwo radzieckie. Ukoronowaniem zarządzeń sowieckich przeciwko Polakom była „Instrukcja o trybie przeprowadzania deportacji antyradzieckiego elementu" - kolonistów, osadników wojskowych i inteligencji. Masowe wywożenie ludności polskiej (celem wykazania niepolskiego

s. 497-502; W 1939 r. diecezja łucka liczyła około 370.000 wiernych obrządku łac., czyli ludności polskiej. Dzieliła się na 16 dekanatów, 169 parafii; M. Malinowski, B. Kołosok, Zarys dziejów diecezji tuckiej oraz katedry św. Piotra i Pawła w Łucku, Kalwaria Zebrzydowska 1993.

${ }^{5}$ M. Wieliczko, Pogranicze niemiecko-radzieckie nad Sanem w latach 1939-1940, „Przemyskie Zapiski Historyczne", 8-9 (1991-1992) s. $151 \mathrm{nn}$.

${ }^{6}$ S. Zych, Biskup Franciszek Barda (1880-1964) i jego losy podczas II wojny światowej, w: Numine Tuo Domine. Księga pamiqtkowa dedykowana Metropolicie Przemyskiemu Księdzu Arcybiskupowi Józefowi Michalikowi w 20. rocznicę święceń biskupich, red. A. Szal, Przemyśl 2006, s. $775-789$.

${ }^{7}$ Borcz, Archidiecezja przemyska, s. 15; J. Ataman, Zarys dziejów diecezji przemyskiej obrzqdku łacińskiego, Przemyśl 1985, s. 79-80.

${ }^{8}$ J. Krochmal, Wstęp, w: J. Smołka, Przemyśl pod sowieckq okupacjq. Wspomnienia z lat 1939-1941, oprac. J. Krochmal, Przemyśl 1999, s. 19.

${ }^{9}$ R. Szawłowski, Wojna Polsko-Sowiecka 1939, Warszawa 1997; tenże, Antypolskie wystapienia na Kresach Wschodnich (1939-1945), w: Encyklopedia „Biatych Plam”, t. 1, Radom 2000, s. 165-169; Hryciuk, Przemiany narodowościowe i ludnościowe w Galicji Wschodniej i na Wołyniu, s. 164. 
charakteru etnicznego tych ziem) zaczęło się w lutym 1940 r. i trwało niemal do czasu niemieckiej agresji na ZSRR. W ten sposób deportowano ponad milion Polaków, a blisko 250 tys. wcielono do Armii Czerwonej ${ }^{10}$.

Jednocześnie na istniejące Kościoły i związki wyznaniowe rozciągnięto sowieckie przepisy regulujące sytuację wyznaniową na tym obszarze. Wprowadzono wiele dokuczliwych dla Kościoła zarządzeń, utrudniających wykonywanie jego misji. Uderzono przede wszystkim w podstawy materialne Kościoła. W grudniu 1939 r. znacjonalizowano mienie kościelne. Umilkły dzwony kościelne, ustały procesje poza obrębem świątyń. Duchowni w większości zrezygnowali z chodzenia w strojach duchownych. Niszczono znajdujące się poza terenem kościelnym miejsca i znaki kultu - figury i krzyże przydrożne. Najdotkliwsze były jednak obciążenia finansowe. Księża jako ,pracownicy kultu” obłożeni zostali najwyższymi stawkami podatku od dochodów osobistych. Do tego dochodziły bardzo wysokie podatki za funkcjonowanie kościoła. Presja ekonomiczna stała się tak dotkliwa, że brano pod uwagę nawet zamknięcie niektórych świątyń. Część księży i sióstr zakonnych szukała na wpół fikcyjnych posad w instytucjach państwowych, np. w szpitalach, dzięki czemu unikała płacenia wysokich podatków. W ślad za usunięciem nauki religii ze szkół wyeliminowano z budynków szkolnych wszelkie symbole religijne (krzyże, obrazy), zamknięto kaplice oraz wycofano z bibliotek książki o tematyce religijnej. Po reorganizacji szkolnictwa na wzór radziecki (styczeń 1940 r.) nastapiła indoktrynacja ateistyczna. Próbom odizolowania młodzieży od Kościoła w pierwszym półroczu 1940 r. sprzyjało zniesienie świąt religijnych oraz wprowadzenie sześciodniówki, która utrudniała regularne uczestnictwo w niedzielnych mszach. Katechizację dla uczniów szkół podstawowych prowadzono przy parafiach. W warunkach półkonspiracyjnych przez cały okres okupacji radzieckiej działało Wyższe Seminarium Duchowne kierowane przez ks. Stanisława Frankla. Prowadzono szeroko zakrojoną akcję charytatywną. W warunkach okupacji radzieckiej księża prócz „ducha wiary” podtrzymywali ducha polskości. Kościół stał się miejscem schronienia „twierdzą polskości”. W mszach i nabożeństwach uczestniczyły tłumy wiernych. Akcentów patriotycznych nie unikano przy urządzaniu wielkanocnych grobów Pańskich czy ołtarzy na trasie

${ }^{10}$ A. Sudoł, Poczatki sowietyzacji Kresów Wschodnich (Jesień 1939), Wybrane problemy polityczne i organizacyjne, Bydgoszcz 1997; A. Głowacki, Sowieci wobec Polaków na ziemiach wschodnich II Rzeczypospolitej 1939-1941, Łódź 19982; W. Bonusiak, Polityka ludnościowa i ekonomiczna ZSRR na okupowanych ziemiach polskich w latach 1939-1941 (, Zachodnia Ukraina” i ,Zachodnia Białoruś”), Rzeszów 2006; R. Wnuk, „Za pierwszego Sowieta”. Polska konspiracja na Kresach Wschodnich II Rzeczypospolitej (wrzesień 1939 - czerwiec 1941), Warszawa 2007; Okupacja sowiecka ziem polskich 1939-1941, red. P. Chmielowiec, Rzeszów-Warszawa 2005; Deportacje i przemieszczenia ludności polskiej w głab ZSRR 1939-1945. Przeglad piśmiennictwa, red. T. Walichnowski, Warszawa 1989; Deportacje obywateli polskich z Zachodniej Ukrainy i Zachodniej Białorusi w 1940 roku, red. W. Komogorow i in., Warszawa 2003; W czterdziestym nas Matko na Sybir zestali. Polska a Rosja 1939-42, wyb. i oprac. J. T. Gross, J. Grudzińska-Gross, Warszawa 1990; G. Hryciuk, Przemiany ludnościowe w Galicji Wschodniej 1939-1945, „Studia Rzeszowskie”, 3(1996) s. 21-51; G. Mazur, Z dziejów sowietyzacji tzw. Zachodniej Ukrainy 1939-1941, „Studia Rzeszowskie", 3 (1996) s. 67-84; E. Czop, Deportacje ludności polskiej z obwodu lwowskiego w 1940 roku, „Studia Rzeszowskie”, 3 (1996) s. 85-105. 
procesji w święto Bożego Ciała. Uczucia narodowe manifestowano szczególnie podczas mszy, w dniach najbardziej związanych z najnowszą historią Polski ${ }^{11}$.

Po agresji Niemiec na ZSRR, wbrew dążeniom Ukraińców do utworzenia niepodległego państwa, Galicja - Małopolska Wschodnia została wcielona do Generalnego Gubernatorstwa, a cześśc Wołynia do Reichkommissariatu Ukraina. Kwintesencją stosunku Ukraińców do Polaków na Kresach były masowe rzezie tysięcy ludności polskiej na Wołyniu i w Małopolsce Wschodniej. Oddziały Ukraińskiej Powstańczej Armii rozpoczęły walkę z ludnością polską. Trudno jest dzisiaj choćby w przybliżeniu określić liczbę Polaków, którzy zginęli w rzeziach ukraińskich. Różni autorzy podają różne liczby ofiar. Według szacunków radzieckich zamordowano około 20.000, natomiast według danych polskich tylko w ciągu 1943 r. zginęło na Wołyniu z rąk Ukraińców około 15.000 Polaków, zaś ogólna liczba Polaków zamordowanych na Wołyniu przez Ukraińców w okresie od marca 1943 r. do czerwca 1944 r. wyniosła około 40.000. Ocenia się, że na byłych terenach wschodnich Polski zginęło około 300.000 Polaków, z czego 80.000 100.000 na samym tylko Wołyniu ${ }^{12}$. O skali rozgrywającego się wówczas dramatu świadczy zarówno korespondencja abpa B. Twardowskiego z abpem A. Szeptyckim $^{13}$, jak i sprawozdania kapłanów rzymskokatolickich przesyłane swoim biskupom w diecezji łuckiej ${ }^{14} \mathrm{i}$ archidiecezji lwowskiej ${ }^{15}$. Jak wynika $\mathrm{z}$ badań zainicjowanych przez członków Światowego Związku Żołnierzy Armii Krajowej - „Do

${ }^{11}$ Położenie ludności polskiej na terytorium ZSRR $i$ wschodnich ziemiach II Rzeczypospolitej w czasie II wojny światowej, red. A. Marszałek, Torun 1990; G. Hryciuk, Polacy we Lwowie 19391944. Życie codzienne, Warszawa 2000; В. Слободян, Римо-католицька церква під час радянської влади в Україні, w: Історія релігії в Україні, t. 4: Католищизм, red. П. Яроцький, Київ 2001, s. 146-167; Lwowskie pod okupacja sowieckq (1939-1941), red. T. Bereza, Rzeszów 2006; S. Bizuń, Historia krzyżem znaczona. Wspomnienia z życia Kościoła katolickiego na Ziemi Lwowskiej 19391945, oprac. J. Wołczański, Lublin 1993; Lwowski bohater ks. Stanisław Frankl (1903-1944), oprac. J. Zimny, Sandomierz, 2000; W. Szetelnicki, Zapomniany lwowski bohater ks. Stanisław Frankl (1903-1944), Roma 1983.

${ }^{12}$ Skalę zbrodni dokonanych przez nacjonalistów ukraińskich na ludności polskiej dokumentują prace m.in.: W. Siemaszko, E. Siemaszko, Ludobójstwo dokonane przez nacjonalistów ukraińskich na ludności polskiej Wotynia 1939-1945, t. 1-2, Warszawa 2000; W. Filar, Wotyń 1939-1944. Eksterminacja czyli walki polsko-ukraińskie, Torun 2003; W. Urban, Droga krzyżowa archidiecezji lwowskiej w latach II wojny światowej 1939-1945, Wrocław 1983; Antypolska akcja nacjonalistów ukraińskich w Małopolsce Wschodniej w świetle dokumentów Rady Głównej Opiekuńczej 1943-1944, oprac. L. Kulińska i A. Soliński, Kraków 2003; A. Korman, Stosunek UPA do Polaków na ziemiach poludniowo-wschodnich II Rzeczypospolitej, Wrocław 2002; Zbrodnie nacjonalistów ukraińskich na ludności cywilnej w południowo-wschodniej Polsce (1942-1947), red. Z. Konieczny, Przemyśl 2001.

${ }_{13}$ J. Wołczański, Korespondencja arcybiskupa Bolesława Twardowskiego z arcybiskupem Andrzejem Szeptyckim w latach 1943-1944, „Przegląd Wschodni”, 2 (1992/1993) z. 2 (6) s. 465-484.

${ }^{14}$ Materiały do dziejów diecezji łuckiej. Relacje o stanie dekanatów i parafii 1941-1944, oprac. M. Dębowska, Biały Dunajec 2005; P. Weiser, Ksiqdz Zygmunt Chmielnicki 1891-1944, Lublin 2001.

${ }^{15}$ J. Wołczański, Eksterminacja narodu polskiego i Kościoła Rzymskokatolickiego przez ukrainskich nacjonalistów w Małopolsce Wschodniej w latach 1939-1945. Materiały źródłowe, cz. 1, Kraków 2005; tenże; Eksterminacja narodu polskiego i Kościoła Rzymskokatolickiego przez ukra- 
2001 r., to jest do rozpoczęcia przez Instytut Pamięci Narodowej prac na temat eksterminacji ludności polskiej, żadna instytucja naukowa nie podjęła badań, których celem było poznanie tej białej plamy najnowszej historii"16

W czasie wojny, również w niemieckiej strefie okupacyjnej działalność duszpasterska została poddana drastycznym ograniczeniom. Zostały zniesione niektóre święta, zakazano odprawiania tzw. pasterki ze względu na godzinę policyjną. Nie zezwolono na wydawanie diecezjalnych pism urzędowych, schematyzmów diecezjalnych oraz czasopism. Zakazano również śpiewania niektórych pieśni i odmawiania niektórych modlitw ${ }^{17}$. W 1940 r. w niemieckiej strefie okupacyjnej udało się wznowić działalność przemyskiego seminarium duchownego w Brzozowie (bez prawa przyjmowania nowych alumnów, które funkcjonowało do 1946 roku $)^{18}$. Niemieckie władze okupacyjne konsekwentnie ograniczając działalność organizacji religijnych na podległym sobie terytorium, popierały jednocześnie wszelkiego rodzaju separatyzmy wyznaniowe ${ }^{19}$. Stolica Apostolska biorąc pod uwagę niektóre ograniczenia władz okupacyjnych przyznała miejscowym biskupom dość szerokie uprawnienia o charakterze duszpasterskim i liturgicznym ${ }^{20}$.

Po zakończeniu II wojny światowej, w wyniku ustaleń w Poczdamie, do 16 sierpnia 1945 r., terytorium metropolii lwowskiej ob. łac., tzn. byłe tereny polskie, należące do województw wołyńskiego, stanisławowskiego, tarnopolskiego, i w dużej części lwowskiego, po zmianach przynależności państwowej oraz zmianach administracyjnych znalazły się w obrębie obwodów wołyńskiego, rowieńskiego, tarnopolskiego, stanisławowskiego - (iwanofrankowskiego) i lwowskie-

ińskich nacjonalistów w Małopolsce Wschodniej w latach 1939-1945. Materiały źródtowe, cz. 2, Kraków 2006.

${ }^{16}$ A. Żupański, Tragiczne wydarzenia za Bugiem i Sanem przed ponad sześćdziesięciu laty. Poznaj werdykt historyków polskich i ukraińskich, Warszawa 2007, s. 7-8. Opracowanie zawiera również zestawienie wybranych pozycji historiografii polskiej, dotyczących tych okrutnych zbrodni ludobójstwa, s. 76-79.

${ }^{17}$ La Chiesa cattolica in Polonia sotto il comunismo (1944-1964), w: Rzeszovien. Beatificationis seu declarationis martyrii Servi Dei Ladislai Findysz Sacerdotis Dioecesani in odium fidei, uti fertur, interfecti († 1964). Positio super martyrio, (współautorzy: S. Nabywaniec, P. Synoś i P. Tarnawski), Roma 2003, s. 44-81; Z. K. Wójcik, Dekanat rzeszowski w latach 1939-1944, „Resovia Sacra", 4 (1997) s. 247.

${ }^{18}$ J. Niemiec, Przemyskie Seminarium Duchowne w Brzozowie 1939-1946, „Studia Rzeszowskie", 4 (1997) s. 65 i 67.

${ }^{19}$ W. Zajączkowski, W obliczu rewolucji. (Rosyjskie prawosławie w latach 1917-44), w: Dar Polski Białorusinom, Rosjanom i Ukraincom na Tysiqclecie ich Chrztu Świętego, red. K. Podlaski, Londyn 1989, s. 96; В. Войналович, Наступ на етноконфесійні осередки як один із засобів здійснення начіональної політики в Украӥні ( друга пол. 40-х - 50-ті роки XX ст.), „3 архівів ВУЧК ГПУ НКВД КГБ”, 1/2 (1997) s. 211. Pismo Alfreda Rosenberga z 13 maja 1943 r. do Komisarzy Rzeszy na Wschodzie.

${ }^{20}$ T. Śliwa, Nadzwyczajne uprawnienia duszpasterskie kapłanów katolickich w Zwiqzku Radzieckim w okresie II wojny światowej, „Premislia Christiana”, 9 (2001) s. 447-449; M. Dębowska, Nadzwyczajne uprawnienia dla biskupów diecezjalnych na terenach RP zajętych przez wojska radzieckie w 1939 roku, „Archiwa Biblioteki i Muzea Kościelne”, 78 (2002) s. 41-64. 
go $^{21}$. Pod względem administracji kościelnej w granicach USRR pozostała część archidiecezji lwowskiej, diecezja łucka, część przemyskiej i zakarpacka ${ }^{22}$. Ukształtowanie się wschodniej granicy Polski na tzw. „linii Curzona” miało więc wpływ na struktury administracji państwowej. Po odpadnięciu od Polski Lwowa, do rangi stolicy województwa, aspirował Rzeszów. Wyzwolony 2 VIII 1944 r. Rzeszów, stał się siedzibą władz wojewódzkich. W skład nowoutworzonej jednostki administracyjnej weszły powiaty $\mathrm{z}$ byłego woj. lwowskiego oraz m.in. powiat jasielski i gorlicki z woj. krakowskiego. Od tego momentu pozostałe w granicach Polski po podziale terytorium archidiecezji lwowskiej i diecezji przemyskiej znalazło się w woj. rzeszowskim ${ }^{23}$. Na terytorium USRR pozostało 400 parafii i 22 księży archidiecezji lwowskiej, 120 parafii i kilku (4) kapłanów diecezji łuckiej ${ }^{24}$. Obszar diecezji przemyskiej25 zmniejszył się (o ok. $7000 \mathrm{~km}^{2}$ ) do $14913 \mathrm{~km}^{2}$. Ludność zamieszkująca zagarnięte tereny wyjechała w większości na tzw. Ziemie Odzyskane, a jej część osiedliła się w polskiej części diecezji. Z diecezji przemyskiej, za granicą państwa, pozostało 646 miejscowości, 5 dekanatów, 70 parafii, 76 kościołów (w tym 6 zakonnych) i ok. 100 kaplic, a także ok. 20 kapłanów wraz z wiernymi, którzy nie wyjechali. Wszyscy ci kapłani zostali w niedługim czasie aresztowani przez władze sowieckie i osadzeni w więzieniach i łagrach. Ponadto zlikwidowano 7 klasztorów męskich i 30 żeńskich ${ }^{26}$. Ks. R. Dzwonkowski jest zdania, że na Ukrainie zachodniej, po tragicznych dla Polaków wydarzeniach z lat 1943-1945 będących wynikiem działania UPA pozostała jedynie niewielka diaspora i około 50 księży polskich, z których do 1953 r. zostało jeszcze aresztowanych około $40^{27}$.

Jeszcze w trakcie działań wojennych, Polski Komitet Wyzwolenia Narodowego (9 IX 1944 r.) zawarł z rządem USRR układ o ewakuacji ludności ukraińskiej $\mathrm{z}$ terytorium Polski i obywateli polskich $\mathrm{z}$ terytorium USRR $^{28}$. Ludność stanęła wówczas przed wyborem, między ojczyzną narodową a ojcowizną. Repatriacja

${ }^{21}$ P. Eberhardt, Polska granica wschodnia 1939-1945, Warszawa [1992]; s. 38-55; tenże, Przemiany narodowościowe na Ukrainie XX wieku, Warszawa 1994, s. 209.

${ }_{22}^{22}$ В. Осадчий, Католицька Церква в Украӥні. Історичний нарис, Лублін 2001, s. 62.

${ }^{23}$ S. Bonusiak, Przemiany gospodarcze w Rzeszowie w latach 1944-1988, „Zeszyty Naukowe Wyższej Szkoły Pedagogicznej w Rzeszowie”, 10 (1993) s. 178; zob. W. Kret, Dzieje parafii świętych Wojciecha i Stanistawa w Rzeszowie w latach 1949-1989, Biecz 2004, s. 30-31.

${ }^{24}$ Por. T. Opas, Archidiecezja w Lubaczowie w latach 1946-1992, „Studia Rzeszowskie”, 3 (1996) s. 115-130; B. Kumor, Historia Kościoła. Czasy wspótczesne 1914-1992, cz. 8, Lublin 1996, s. 208- 209, 213.

${ }^{25}$ Zmiany terytorialne diec. przemyskiej od wydania ostatniego schematyzmu 1938 r., „Kronika Diecezji Przemyskiej”, 40 (1947) z. 1-4, s. 32-33.

${ }_{26}$ Śliwa, Diecezja przemyska, s. 172-199.

${ }^{27}$ R. Dzwonkowski, Duchowieństwo katolickie obrzqdku tacińskiego represjonowane w ZSRS w latach 1939-1987. (Materiaty do stownika biograficznego), „Przegląd Wschodni”, 23 (2000) t. 6, z. 3 , s. 529.

${ }^{28}$ Samo zagadnienie jak i dotychczasowa historiografia na temat przesiedleń polskich i ukraińskich zostały omówione w Polska i Ukraina w latach trzydziestych i czterdziestych XX wieku. Nieznane dokumenty $z$ archiwów slużb specjalnych, t. 2: Przesiedlenia Polaków i Ukrainców 19441946, Warszawa 2000, s. 35-59, 263-278. 
miała na celu m.in. ograniczenie działalności Kościoła katolickiego na Ukrainie, tzn.: zobowiązano się w niej do przymusowej repatriacji duchowieństwa i najbardziej zaangażowanych wiernych ${ }^{29}$. Władzom sowieckim zależało bowiem na tym, aby w ramach przesiedleń Polaków z terenów Ukrainy wyjechała inteligencja polska. Wynikiem tego posunięcia był wyjazd na zachód w latach 1944-1948 z ziem włączonych do Ukrainy niemal 2500 osób duchownych różnych wyznań oraz około 10\% ludności polskiej, a z Ukrainy Zazbruczańskiej, przyłączonej do ZSRR traktatem ryskim z 1921 r. -434 duchownych. Wśród nich dominowali również przedstawiciele wyznania rzymskokatolickiego ${ }^{30}$. W rzeczywistości umowa repatriacyjna spowodowała masowy odpływ ludności pochodzenia polskiego z terenów zachodniej Ukrainy. Przesiedlenia odbywały się całymi parafiami; polskie wsie i kościoły pustoszały. Swoją ojcowiznę na Ukrainie opuściło blisko 800 tys. Polaków $^{31}$. Znane są przypadki, kiedy władze mimo zawartych umów czyniły trudności wyjeżdżającym Polakom, a mieszkańców niektórych wiosek w ogóle nie poinformowały o możliwości wyjazdu do Polski ${ }^{32}$.

Sytuacja związana z wyjazdem zdezorientowała duchowieństwo katolickie. Lwowski abp E. Baziak uważał, „że jeśli wyjeżdżają wierni, to i kapłan może wyjechać; jeśli zostają i on powinien zostać". Sam arcybiskup był skłaniany do wyjazdu przez sowieckie służby specjalne. Jurysdykcję kościelną przejęli kapłani, którzy pozostali. Oni też organizowali obsadę parafii, posługę duszpasterską ${ }^{33}$.

${ }^{29}$ Войналович, Наступ на етноконфесійні осередки, s. 221; tenże, Римо-католицькі громади України у вимірах державної релігійної політики (II пол. 40-х - 50-ті роки XX ст.), w: Історія Украӥни. Маловідомі імена, подї, факти, П. Т. Тронько, О. Г. Бажан, Л. А. Гречина, Київ 1999, s. 153; Е. Kołodziej, Repatriacja ludności polskiej z Ukrainy w latach 1944-1946 $w$ świetle dokumentów przechowywanych w Archiwum Akt Nowych, „Teki Archiwalne”, seria nowa, 3/25 (1998) s. 113-139; G. Hryciuk, Zmiany ludnościowe i narodowościowe w Galicji Wschodniej i na Wotyniu w latach 1939--1948, w: Przemiany narodowościowe na Kresach Wschodnich II Rzeczypospolitej 1931-1948, red. S. Ciesielski, [Toruń 2003]; s. 149-240.

${ }^{30}$ Hryciuk, Przemiany narodowościowe i ludnościowe w Galicji Wschodniej i na Wotyniu, s. 254; M. M., Historia Kościoła we Lwowie od 1939 roku, „Biuletyn Koła Lwowian”, nr 53, Londyn 1987, s. 24; E. Kamilewski, Kościót katolicki na Zachodniej Ukrainie po II wojnie światowej, w: Polacy w Kościele katolickim w ZSRR, red. E. Walewander, Lublin 1991, s. 293.

${ }^{31}$ B. Cywiński, Ogniem próbowane. $Z$ dziejów najnowszych Kościoła katolickiego w Europie Środkowo-Wschodniej, t. 2, Lublin 1990, s. 208; O. Sawczuk, W. Serhijczuk, Osobliwości przesiedlenia polskiej ludności Wolynia do Polski w latach 1944-1946, w: Polacy i Kościót rzymskokatolicki na Wolyniu w latach 1918-1997. Materiały z międzynarodowej sesji naukowej zorganizowanej w Lublinie w dniach 9-10 grudnia 1997 r., red. L. Popek, Lublin 1999, s. 189-203; L. Popek, Uchodźcy z Wotynia w latach 1943-1944 w świetle dokumentów przechowywanych w Archiwum Państwowym w Lublinie, „Rocznik Historyczno-Archiwalny”, 10 (1995); S. Ciesielski, Polacy w Kazachstanie 1940-1946. Zestańcy lat wojny, Wrocław 1997, s. 67-69.

${ }^{32}$ H. M. Wilk, „Ty nie zginiesz”, Lublin 2001, s. 20, 76, 87, 93.

${ }^{33}$ J. Żurek, Lwowskie losy abp. Eugeniusza Baziaka, „Biuletyn Instytutu Pamięci Narodowej”, 12 (47) (2004) s. 36; Осадчий, Католицька Церква в Україні, s. 62; Ł. Korda, Działalność polskiego duchowieństwa katolickiego w ZSRR (1945-1980), w: Dar Polski Białorusinom, Rosjanom i Ukraińcom na Tysiqclecie ich Chrztu Świętego, red. K. Podlaski, Londyn 1989, s. 166-174; J. Wołczański, Ksiadz biskup Jan Olszański. Duszpasterz - patriota-człowiek, w: Pasterz i twierdza. 
Głównym instrumentem w kreowaniu polityki wyznaniowej na terytorium ZSRR jeszcze w okresie II wojny światowej stała się Rada ds. Cerkwi Prawosławnej. Utworzona z polecenia J. Stalina 14 września 1943 r., działała przy Radzie Komisarzy Ludowych. W praktyce, Rada była filią Ministerstwa Bezpieczeństwa Państwowego ZSRR. Rok później, 19 maja 1944 r. w „trosce” o zgodną z prawem o kultach działalność innych wyznań powołano Radę ds. Kultów Religijnych, w której kompetencji była działalność Kościoła katolickiego. Przez powołanie Rds.KR władze sowieckie usiłowały kontrolować ustrój wewnętrzny Kościoła domagając się od swoich urzędników szczegółowych sprawozdań. Na swoich przedstawicieli - pełnomocników w terenie, Rada powołała pracowników służby bezpieczeństwa. Za najważniejsze zadania pełnomocnika uznano wówczas przeprowadzenie rejestracji budynków modlitewnych, organów wykonawczych organizacji religijnych i osób duchownych. Pełnomocnik wypełniał swoje zadania w ścisłej współpracy z władzami lokalnymi szczebla obwodowego, rejonowego i wiejskiego, tak, by zgodnie z zaleceniami Rady z 19 sierpnia 1946 r. „Ukraińcom, kiedyś „katolicyzowanym” umiejętnie wszelkimi dostępnymi środkami stworzyć możliwość powrotu do Cerkwi prawosławnej"34.

Intensywnie realizowano politykę wyznaniową kontynuującą dotychczasowe metody walki. Duchowieństwo, które nie skorzystało z repatriacji w $1945 \mathrm{r}$. wraz $\mathrm{z}$ biskupem A. Szelążkiem w większości aresztowano, zesłano na pobyt w łagrach - do 25 lat $^{35}$. W przypadkach, kiedy kapłan odmawiał rejestrowania się w urzędach, ,polecono wzywać do siedziby władz lokalnych wpływowych katolików i wyjaśniać im, iż kościół pozostanie zamknięty i opieczętowany do momentu, aż się ksiądz nie zarejestruje. Kiedy zaś ksiądz przy wypełnianiu ankiety w rubryce o obywatelstwie nie napisał nic lub to, że jest Polakiem, wzywano przedstawicieli parafii i informowano ich o niemożliwości rejestracji osób nie mających obywatelstwa ZSRR ${ }^{36}$. Władze wszelkimi możliwymi sposobami usiłowały ograniczyć misjęKościołakatolickiego.Konsekwencjazjakąwładze sowieckie walczyły z Kościołem i jego duchowieństwem sprawiła, że w wyniku nierównej walki zanikały struktury kościelno-administracyjne ${ }^{37}$. Organy władzy redukując systematycznie struktury Kościoła i eliminując kler z życia społecznego zacierały na tym terenie

Księga Jubileuszowa dedykowana księdzu biskupowi Janowi Olszańskiemu ordynariuszowi diecezji w Kamieńcu Podolskim, red. J. Wołczański, Kraków 2001, s. 9-19.

${ }^{34}$ Szymański, Kościót katolicki na Podolu. Obwód winnicki 1941-1964, Lublin 2003, s. 145.

${ }^{35}$ W. Osadczy, Wierzyli wbrew nadziei. Z dziejów przetrwania Kościoła łacińskiego na Ukrainie radzieckiej w okresie powojennym, „Ethos”, 14 (2001) nr 1-2, s. 151-164.

${ }^{36}$ J. Szymański, Kościót katolicki na Podolu, s. 136-139

${ }^{37}$ W. Piasecki, Działalność ks. J. Rutkowskiego-ostatniego administratora diecezji łuckiej w latach 1945-1954 w świetle dokumentów Wolyńskiego Archiwum Obwodowego w Łucku, w: Polacy i Kościót rzymskokatolicki na Wołyniu w latach 1918-1997. Materiały z międzynarodowej sesji naukowej zorganizowanej w Lublinie w dniach 9-10 grudnia 1997 r., red. L. Popek, Lublin 1999, s. 75-88; J. Stocki, Kościót rzymskokatolicki na Ukrainie Zachodniej na przykładzie Tarnopolszczyzny w latach 1946-1989, „Pamięć i Sprawiedliwość”, 1 (7) (2005) s. 203-226; Księdza Kazimierza Fleischhackera Kronika parafialna Chomiakówki w tarnopolskim (1939-1955), oprac. J. Wołczański, „Nasza Przeszłość”, 94 (2000) s. 393-480. 
nie tylko ślady religijności, ale przede wszystkim polskości ${ }^{38}$. Jednym z priorytetowych dążeń było ograniczenie wpływów Stolicy Apostolskiej na działalność Kościoła katolickiego i utworzenie autokefalii Kościoła rzymskokatolickiego na Ukrainie (jej istnienie miało doprowadzić do odłączenia się Kościoła katolickiego od Stolicy Apostolskiej) $)^{39}$.

Te założenia próbowano zrealizować, organizując „Bractwo Katolików Związku Radzieckiego”. Członków Bractwa przekonywano do zerwania więzi z Rzymem, zrezygnowania z języka łacińskiego i rytuału katolickiego i podporządkowania się kanonicznie patriarsze moskiewskiemu. Wysiłki pracowników urzędu pełnomocnika Rds.KR pozostały w sferze projektu, który mimo oporu ze strony księży miał być realizowany.

Jeszcze w 1944 r. KC KP(b) przyjął postanowienie „O organizowaniu naukowo-oświatowej propagandy”. Zobowiązano wówczas wszystkie organizacje i instytucje partyjno-państwowe do jej propagowania. Wskazania te zostały doprecyzowane w tym samym jeszcze roku w „Liście zamkniętym KC KP Ukrainy w sprawach religii", jaki otrzymały organizacje partyjne w republice. Pomimo zorganizowania pełnego nadzoru nad działalnością Kościoła katolickiego Rds.KR w Moskwie poleciła 7 II 1947 r. w związku ze zbliżającymi się wyborami do Rady Najwyższej USRR swoim podwładnym zwrócenie uwagi na „nacjonalistycznoreakcyjny element katolicki”. Władze obawiały się bowiem sabotażu ze strony duchowieństwa i wiernych. W tymże samym roku propagowanie ideologii ateistycznej powierzono utworzonemu na bazie Związku Wojujących Bezbożników Towarzystwu Krzewienia Nauki i Kultury Świeckiej „Znanie”40.

Zgodnie z postanowieniami jałtańskimi o ustroju Polski miały zdecydować wolne wybory. Nowe komunistyczne władze mając za sobą „parasol sowiecki” przystapiły do walki z Kościołem, chociaż ówczesna sytuacja polityczna nie sprzyjała otwartej konfrontacji narzuconych przez Stalina władz z cieszącym się autorytetem Kościołem. Niemniej bardzo ostrożnie ale konsekwentnie przystąpiono do całkowitego podporządkowania Kościoła nowej władzy, zerwano konkordat, sfałszowano wybory, wyeliminowano opozycję $e^{41}$, likwidowano organiza-

${ }^{38}$ J. Wołczański, ,Aktywny polski nacjonalista”. Sowieckie represje wobec ks. Ignacego Chwiruta na Ukrainie sowieckiej po II wojnie światowej, w: Kościół na drogach historii. Księga jubileuszowa dedykowana Księdzu Profesorowi Doktorowi Tadeuszowi Śliwie, red. J. Wołczański, LwówKraków 1999, s. 363-380; tenże, Sowieckie prześladowania jezuitów lwowskich u schyłku II wojny światowej w świetle źródeł NKWD, w: Jezuicka Ars Historica. Prace ofiarowane Księdzu profesorowi Ludwikowi Grzebieniowi SJ, red. M. Inglot, S. Obirek, Kraków 2001, s. 621-644.

${ }^{39}$ Szymański, Kościół katolicki na Podolu, s. 145-146.

${ }^{40}$ Tamże, s. 178.

${ }^{41}$ Z. Zieliński, Kościół katolicki w Polsce 1944-2002, Radom 2003; K. Jaworska, Relacje między państwem a Kościołem katolickim w Polsce w latach 1945-1956, „Resovia Sacra”, 13 (2006), s. 233-251; H. Borcz, Represyjna polityka władz komunistycznych wobec diecezji przemyskiej obrzadku łacińskiego w latach 1944-1956, w: Powiat przemyski w latach 1944-1956, red. K. Kaczmarski i M. Krzysztofiński, Przemyśl 2006, s. 97-141; Z. Nawrocki, Zamiast wolności. UB na Rzeszowszczyźnie, Rzeszów 1998; M. Dobrzyński, Gehenna Polaków na Rzeszowszczyźnie w latach 1939-1948, Wrocław 2002. 
cje kościelne ${ }^{42}$. Wbrew oczekiwaniom zawartym między rządem a Episkopatem „Porozumienie” z 14 IV 1950 stworzyło tylko pozory praworządności, nad którymi miał czuwać Urząd do Spraw Wyznań ${ }^{43}$.

Na terenie łacińskiej diecezji przemyskiej, władze komunistyczne realizowały swoje plany już od 1944 r., głównie za pomocą Urzędu Bezpieczeństwa ${ }^{44}$. Represje zapoczątkowało zamordowanie kapelana Okręgu Rzeszowskiego AK ks. Michała Pilipca ps. „Ski” ${ }^{45}$. Potem aresztowano kilkunastu księży, a kilkudziesięciu innych zmuszono do ukrywania się poza diecezją ${ }^{46} \mathrm{~W}$ obawie o utratę życia, m.in. na emigrację udał się kapelan AK ks. Mieczysław Bossowski ${ }^{47}$. W sumie, w latach 1939-1945 tylko w diecezji przemyskiej zginęło bądź zostało zamordowanych 35 kapłanów (14 w obozach koncentracyjnych, 4 zamordowanych przez UPA). W więzieniach znalazło się ponad 90 kapłanów, kilkunastu ukrywało się przed aresztowaniem, kilkudziesięciu znalazło się poza granicami kraju. Wielu księży włączyło się w działalność niepodległościową oraz w tajne nauczanie ${ }^{48}$.

${ }^{42}$ D. Zamiatała, Caritas. Działalność i likwidacja organizacji 1945-1950, Lublin 2000; M. Krzysztofiński, Inwigilacja Kościoła rzymskokatolickiego przez WUBP/WU ds. BP w Rzeszowie i jednostki mu podległe w latach 1944-1956. Zarys problematyki, w: Męczennicy i świadkowie wiary. Represje komunistyczne wobec duchowieństwa na Rzeszowszczyźnie, red. S. Nabywaniec, Rzeszów 2006, s. 125-144.

${ }_{43}$ Jednostka administracji państwowej Polskiej Rzeczypospolitej Ludowej powołana ustawą z dnia 19 kwietnia 1950. Urząd był częścią aparatu kontroli i represji państwa wobec kościołów i związków wyznaniowych. Współpracował w tym celu m.in.: z Ministerstwem Oświaty (nauczanie religii, szkół wyznaniowych, seminariów duchownych), Ministerstwem Finansów (polityka podatkowa), Ministerstwo Budownictwa (budownictwo sakralne). Ściśle współpracował także z Służbą Bezpieczeństwa. Został zlikwidowany przez Sejm 23 listopada 1989.

${ }^{44}$ Z. Nawrocki, Zamiast wolności. UB na Rzeszowszczyźnie 1944-1949, Rzeszów 1998; M. Dobrzański, Gehenna Polaków na Rzeszowszczyźnie w latach 1939-1948, Wrocław [2002]; D. Iwaneczko, Urzad Bezpieczeństwa w Przemyślu 1944-1956, Rzeszów 2004; Powiat przemyski w latach 1944-1956, red. K. Karczmarski, M. Krzysztofiński, Przemyśl 2006.

${ }^{45}$ G. Brzęk, Ksiadz Michat Pilipiec. Bohater i męczennik sprawy polskiej, Lublin 1995.

${ }^{46}$ P. Chmielowiec, Stan badań nad stosunkami Państwo - Kościół w województwie rzeszowskim w latach 1944-1989, w: Męczennicy i świadkowie wiary. Represje komunistyczne wobec duchowieństwa na Rzeszowszczyźnie, red. S. Nabywaniec, Rzeszów 2006, s. 185-190. Autor przytacza bogatą literaturę dotyczącą poszczególnych duchownych poddanych represjom ze strony władz komunistycznych.

${ }^{47} \mathrm{H}$. Borcz, Represyjna polityka władz komunistycznych wobec diecezji przemyskiej obrzqdku tacińskiego w latach 1944-1956, w: Powiat przemyski w latach 1944-1956, red. K. Karczmarski, M. Krzysztofiński, Przemyśl 2006, s. 103-108.

${ }^{48}$ Chmielowiec, Stan badań nad stosunkami Państwo - Kościót, s. 184-189; Świadkowie wiary Diecezji Przemyskiej z lat 1939-1964, red. S. Zygarowicz, W. Jedynak, Przemyśl 2001; R. Terlecki, Udziat duchowieństwa $w$ ruchu oporu $w$ regionie brzozowskim, w: Chwalcie z nami Paniq Świata. Z dziejów Kościoła na ziemi brzozowskiej, Kraków b.r., s. 219-223; P. Pratko, Życie i działalność ks. Stanisława Baka (1908-1983), Lublin 2007 [mps, Archiwum KUL]. 
Problematyka dotycząca ziem wschodnich II Rzeczpospolitej zyskała prawo obywatelstwa we wszelkiego rodzaju publikacjach dopiero w latach dziewięćdziesiątych. Pojedyncze próby podejmowane były wcześniej przede wszystkim $\mathrm{w}$ środowiskach emigracyjnych ${ }^{49}$. Na początku lat osiemdziesiątych do grona badaczy tej problematyki dołączył Z. Fijałkowski ${ }^{50}$, czy też B. Kumor i Z. Obertyński $^{51}$.

Historiografię dotyczącą dziejów metropolii lwowskiej w tym okresie zapoczątkowała publikacja, Życie religijne w Polsce pod okupacja 1939-1945. Metropolie wileńska i lwowska, zakony ${ }^{52}$, będąca wynikiem sympozjum zorganizowanego przez ks. Z. Zielińskiego w Katolickim Uniwersytecie Lubelskim w 1982 r. Jak zaznaczył we wstępie sam redaktor, książka była w zamierzeniu zaproszeniem do dyskusji, w praktyce zaś stała się dobrze osadzonym w kontekście punktem wyjściowym dla dalszych badań nad dziejami Kościoła w ich burzliwym okresie okupacji niemieckiej i sowieckiej. Ze względu jednak na czas jej powstania, cień na opracowanie rzuciła cenzura. Fakty dotyczące bowiem okupacji sowieckiej musiały liczyć się z ,wrażliwym” okiem cenzora. Dlatego też uwzględniały je na tyle, na ile pozwalały ówczesne władze, a potem źródła. Nie oznacza to wcale, że tymi sprawami nikt się nie zajmował.

Pierwsze próby „rejestracji szkód wojennych” w diecezji przemyskiej podjęto bezpośrednio po zakończeniu II wojny światowej, z inicjatywy krakowskiej Kurii książęco-metropolitalnej, jeszcze w lipcu 1945 r. Zobowiązano wówczas wszystkich proboszczów i administratorów parafii od wypełnienia i przesłania do końca sierpnia 1945 r. w tym celu odpowiednich kwestionariuszy ${ }^{53}$. Działaniom tym

${ }^{49}$ J. Siedlecki, Losy Polaków w ZSRR w latach 1939-1986, Londyn 1988; Z. S. Siemaszko, W sowieckim osaczeniu, Londyn1991.

${ }^{50}$ Kościół katolicki na ziemiach polskich w latach okupacji hitlerowskiej, Warszawa 1983.

${ }^{51}$ Martyrologium Narodu i Kościoła (1939-1945), t. 2, cz. 2, w: Historia Kościoła w Polsce, red. B. Kumor, Z. Obertyński, Poznań 1979.

${ }^{52}$ Red. ks. Z. Zieliński, Katowice 1992.

${ }^{53}$ Archiwum Archidiecezjalne w Przemyślu, b. sygn., Okólniki diec. przem. 1945. L. 1048/45. Kopia ze zbiorów własnych ks. S. Zycha.

„Do Przewielebnego Księdza Proboszcza w ........ Podczas wojny 1939-1945 roku Kościół w Polsce poniósł niepowetowane straty nie tylko wskutek bezpośrednich działań wojennych, lecz bardziej jeszcze z powodu systematycznego, wyrafinowanego prześladowania przez Niemców. Ginęli najlepsi jego synowie, zapadały się w gruzy świątynie, rozluźniała się więź religijna a w wielu okolicach zamarł zupełnie kult Boży.

Teraz gdy z woli Opatrzności, odzyskaliśmy niepodległość mamy obowiązek zsumować wszystkie straty. Domaga się tego od nas krew bohaterów nieznanych dotąd szerszemu ogółowi, których imiona powinniśmy uratować przed zapomnieniem. Należy się to przyszłym pokoleniom, które będą chciały wiedzieć, ile kosztowała nas wolność. Będzie to zarazem najwymowniejsza i najskuteczniejsza apologia Kościoła. Wreszcie nasz własny interes każe nam przeprowadzić statystykę tego rodzaju, żeby móc zgłosić na forum międzynarodowym swe prawa do odszkodowania.

Dlatego uważamy sobie za obowiązek sumienia dokonać możliwie najdokładniejszej rejestracji szkód wojennych wyrządzonych Kościołowi w Polsce. Pragniemy oprzeć się na materiale, który 
przewodził ojciec Wł. Szołdrski - redemptorysta ${ }^{54}$. Na wyniki wspomnianego kwestionariusza powołuje się w swoim opracowaniu ks. T. Sliwa ${ }^{55}$.

Do tej formy udokumentowania sytuacji i strat Kościoła przemyskiego w latach 1939-1951 powrócono po trzydziestu latach, na prośbę Instytutu Geografii Historycznej Kościoła w Polsce przy KUL ${ }^{56}$. Kuria Biskupia w Przemyślu w listopadzie $1976 \mathrm{r}$. na prośbę Instytutu rozesłała ankietę ${ }^{57}$ - Kwestionariusz dla świadków udziału duchownych polskich w walce z okupantem hitlerowskim w II wojnie światowej i sytuacji Kościoła w diecezji przemyskiej w okresie okupacji. Wyniki ankiet w formie maszynopisu przedstawił ks. J. Rąb, Parafie diecezji przemyskiej w l. 1939-195158.

Kolejną próbą zmierzenia się z tym swoistym wyzwaniem, było opracowanie ks. Wł. Piętowskiego, Stosunki polsko-ukraińskie po wybuchu II wojny światowej. Zarys, Czarna k. Łańcuta 1988. Autor opracowania, wspomniał, że ,już ksiądz biskup Franciszek Barda miał zlecić któremuś z księży profesorów przemyskich zebranie od naocznych świadków relacji o tych wydarzeniach (...). Niestety, nie zostało to wówczas zrobione" (s. 5). Podobnie jak poprzednie, tak i to opracowanie nie doczekało się publikacji. Przechowywane jest w Archiwum Archidiecezjalnym w Przemyślu. W tym wypadku Autor zgodnie z poleceniem ówczesnego ordynariusza przemyskiego ks. bpa I. Tokarczuka „miał wypełnić lukę historyczną o lokalnym konflikcie polsko-ukraińskim na terenie diecezji przemyskiej

będzie miał wartość historycznego dokumentu. W tym celu przesyłamy Księdzu Proboszczowi Kwestionariusz, który prosimy wypełnić i zaopatrzyć własnoręcznym podpisem i pieczątką parafialną. (...)”. Kwestionariusz dotyczył: Księży, wiernych, świątyń, cmentarzy, ośrodków kultu, budynków, pracy duszpasterskiej, działalności charytatywnej organizacji kościelnych, udziału księży w niekościelnych organizacjach charytatywnych, majątku kościelnego.

${ }^{54} \mathrm{~W}$. Szołdrski, Martyrologium duchowieństwa polskiego pod okupacjq niemiecka $w$ latach 1939-1945, Rzym 1965.

${ }^{55}$ Śliwa, Diecezja przemyska, s. 172-199.

${ }^{56}, \mathrm{~W}$ związku z 600-leciem naszej diecezji zamierzamy opracować historyczny schematyzm zawierający szczegółowe dane o losach i funkcjonowaniu instytucji kościelnych oraz dane o duchownych naszej diecezji i ich wojennych losach i funkcjach w 1.1939-1951. (...) Materiały zgromadzone przez niniejszą ankietę posłużą również do opracowania Atlasu Historycznego Chrześcijaństwa w Polsce przez Instytut Geografii Historycznej Kościoła w Polsce przy Katolickim Uniwersytecie Lubelskim. Ankieta niniejsza jest nadto przygotowaniem naszej diecezji do udziału w Światowym Kongresie Historyków, który odbędzie się w Polsce w 1978 r. na temat m.in. Kościołów w krajach okupowanych przez III Rzeszę”, w: J. Rąb, Parafie diecezji przemyskiej w latach 1939-1951, s. 9.

${ }^{57}$ Ankieta zawierała dane o ankietowanym, relacje kapelanów wojskowych (względnie o kapelanach), udział w ruchu oporu, współdziałanie z akcją zbrojną ruchu oporu, tajne nauczanie, księża w więzieniach i obozach koncentracyjnych, duszpasterstwo w podtrzymywaniu ducha narodowego, działalność charytatywna duchownych - w sumie 115 pytań. W ankiecie zwrócono uwagę, że ma ona „na celu głównie przypomnienie wypadków tamtych czasów. (...) Każda odpowiedź na ankietę jest przyczynkiem do rekonstrukcji brakującej dokumentacji”. Ankieta zawierała również prośbę o wskazanie osób, które mogłyby bardziej wyczerpująco udzielić informacji na temat poszczególnych duchownych lub działalności Kościoła w czasie wojny.

${ }^{58}$ Archiwum Archidiecezjalne w Przemyślu, Seria prac Kolegiackiej Kapituły Brzozowskiej Nr 20, Iwonicz Zdrój 1978. 
i sześciu pozostałych" - pińskiej, łuckiej, lwowskiej, siedleckiej, lubelskiej i tarnowskiej. Na 400 stronach maszynopisu Autor omówił: rozmieszczenie ludności polskiej i ukraińskiej, świadomość narodową Ukraińców i genezę skrajnego ukraińskiego nacjonalizmu. Autor nie ukrywał, że zebrany materiał „pozwolił dać zaledwie zarys tamtych bolesnych drażliwych dla obu narodowości wydarzeń”, a samo opracowanie jest otwarte na uzupełnienia i sprostowania.

Taki cel zapewne przyświecał J. Drausowi i J. Musiałowi, którzy częściowo urzeczywistnili założenia ordynariusza przemyskiego ks. bpa I. Tokarczuka i Instytutu Geografii Historycznej Kościoła w Polsce przy KUL, by poza cenzurą w oparciu o wspomnianą wyżej ankietę syntetyzująco opracować: 1) problematykę podwójnego doświadczenia okupacyjnego; 2) dzieje poszczególnych dekanatów wchodzących w skład diecezji w momencie wybuchu II wojny światowej; 3) zaangażowanie poszczególnych wspólnot zakonnych. W rzeczywistości zamierzenia w pełni zrealizowano tylko w stosunku do punktu trzeciego, przybliżając skalę oddziaływania 35 wspólnot zakonnych ${ }^{59}$.

Niemniej dysponujemy już znaczną wiedzą o losach duchowieństwa rzymskokatolickiego i wiernych w poszczególnych diecezjach, dekanatach, województwach Drugiej Rzeczypospolitej, radzieckich obwodach ${ }^{60}$, regionach ${ }^{61}$, parafiach ${ }^{62}$. Wiedza ta zawarta jest również $\mathrm{w}$ albumach ${ }^{63}$, opublikowanych dokumentach ${ }^{64}$,

${ }^{59}$ Diecezja przemyska w latach 1939-1945. t. 3: Zakony, red. J. Draus, J. Musiał, Przemyśl 1990.

${ }^{60}$ Stocki, Kościół rzymskokatolicki na Ukrainie Zachodniej, s. 203-226; A. Czajkowski, Niewola za obce i swoje grzechy. Jeńcy w obozach na Ukrainie 1939-1953, red. P. P. Wieczorkiewicz, Warszawa [2003].

${ }^{61}$ S. Śliwa, Duchowieństwo dekanatu dynowskiego w okresie okupacji 1939-1944, Lublin 1983; M. Lignowski, Duchowieństwo dekanatu brzozowskiego w okresie okupacji 1939-1944, Lublin 1983; A. Michna, Dekanat tańcucki w okresie okupacji hitlerowskiej 1939-1945, Lublin 1999; I. Kozimala-Lewandowska, Dekanat sieniawski obrzadku tacińskiego w latach 1939-1945, „Zeszyty Muzealne. Muzeum w Jarosławiu”, 2 (1997/98) s. 69-94; Z. K. Wójcik, Dekanat rzeszowski w latach 1939-1944, „Resovia Sacra”, 4 (1997) s. 243-276; M. Matysiak, M. Rudnicka, Z. Świstak, Kościót katolicki w jasielskim 1939-1945, Brzozów 1991; P. Bartnik, J. Koziarz, Dekanaty leżajski i sokołowski w latach okupacji hitlerowskiej, Przemyśl 1992.

${ }^{62}$ F. Malak, Dzieje parafii Tyczyn, Tyczyn 1996; J. Rąb, Kościelne dzieje Brzozowa, Brzozów 1993; Z. i Z. Cmiel, Historia jednego miasta nad Sanem, Rudnik 1998; 400 lat parafii w Sarzynie (1598-1998), red. J. Półćwiartek, Nowa Sarzyna 2000; B. Gajewski, Besko. Wieś nad Wisłokiem, Rzeszów 1996; Kościoly, klasztory i parafie dawnego Rzeszowa. Materiały z sesji naukowej zorganizowanej dla uczczenia Wielkiego Jubileuszu Chrześcijaństwa 15-16 XI 2000 r., red. M. Jarosińska, Rzeszów 2001; M. Lech, B. Skała, Dzieje parafii w Zaczerniu, Rzeszów 1999; K. Ożóg, Dzieje parafii Górno 1599-1999, Górno-Rzeszów 1999.

${ }^{63}$ Wotyń. Ocalić od zapomnienia, oprac. L. Popek, Lublin 1997; J. Wołczański, Między zagłada a przetrwaniem. Wybrane obiekty sakralne archidiecezji lwowskiej i diecezji przemyskiej obrzadku tacińskiego na Ukrainie Zachodniej 1945-1991, Kraków 2005; M. Buczek, I. Sedelnyk, Archidiecezja lwowska obrzqdku łacińskiego. Opowieść ilustrowana, t. 1, Parafie, kościoły oraz kaplice (obw. Lwowski), Lwów 2004; M. Buczek, I. Sedelnyk, Archidiecezja lwowska obrzqdku łacińskiego. Opowieść ilustrowana, t. 1: Parafie, kościoły oraz kaplice (obw. Czerniowiecki, Iwano-Frankowski i Tarnopolski), Lwów 2006. (opracowania w jęz. ukraińskim).

${ }^{64}$ Aparat bezpieczeństwa w Polsce w latach 1944-1956, Taktyka, strategia, metody, cz. 1: Lata 1945-1947, oprac. A. Paczkowski, „Dokumenty do dziejów PRL, z. 5, Warszawa 1994; Aparat 
pamiętnikach - wspomnieniach ${ }^{65}$, korespondencji ${ }^{66}$, w licznych artykułach i opracowaniach będących wynikiem konferencji naukowych ${ }^{67}$. Swój wkład w opracowywanie tych dziejów mają: ks. J. Wołczański, bp W. Urban, ks. T. Śliwa, ks. H. Borcz, ks. R. Dzwonkowski [Odrodzenie Kościoła katolickiego obrzqdku łacińskiego $w$ ZSRR, w: Polacy $w$ Kościele katolickim $w$ ZSRR, red. E. Walewander, Lublin 1991, s. 213-257; Leksykon duchowieństwa polskiego represjonowanego w ZSRS 1939-1988, Lublin 2003; Odrodzenie Kościoła katolickiego na Ukrainie środkowej, potudniowej $i$ wschodniej w czasie II wojny światowej $i$ bezpośrednio po jej zakończeniu (1941-1948), w: Pasterz i twierdza. Ksiega Jubileuszowa dedykowana księdzu biskupowi Janowi Olszańskiemu ordynariuszowi diecezji w Kamieńcu Podolskim, red. J. Wołczański, Kraków 2001, s. 24-26; Męczeństwo chrześcijan na Wschodzie, „Ethos” 14(2001) nr 1-2, s. 125-138; Polacy na dawnych kresach wschodnich. Z problematyki narodowościowej i religijnej, Lublin 1994; Stan badań nad historia Kościoła i życiem religijnym katolików obrzqdku tacińskiego w ZSRR (1917-1990), w: Mniejszości polskie i Polonia w ZSRR, red. H. Kubiak, Wrocław 1992, s. 103-119]; ks. J. Szymański[Kościót katolicki na Podolu. Obwód winnicki 1941-1964, Lublin 2003; Franciszkanie na Podolu (19411964) - Świadkowie Wiary i Nadziei, „Studia Franciszkańskie” 13 (2003), s. 565580; Hilary Marcin Wilk OFMCap - syn ziemi kolbuszowskiej (1917-1998), w: Ecclesiae, Patriae et Homini serviens. Księga pamiatkowa dedykowana Księdzu Biskupowi Kazimierzowi Górnemu z okazji 70. rocznicy urodzin oraz piętnasto-

bezpieczeństwa. Taktyka, strategia, metody, cz. 2: Lata 1948-1949, oprac. A. Paczkowski, „Dokumenty do dziejów PRL, z. 9, Warszawa 1996; Aparat bezpieczeństwa w Polsce w latach 1950-1952, Taktyka, strategia, metody, wybór i oprac. A. Dudek, A. Paczkowski, Warszawa 2000; P. Raina, Kościót katolicki a państwo w świetle dokumentów (1945-1989), t. 1-3, Poznań 1994-1995; Polska $i$ Ukraina $w$ latach trzydziestych $i$ czterdziestych XX wieku. Nieznane dokumenty z archiwów stużb specjalnych, t. 6, Operacja ,SEJM” 1944-1946, Warszawa - Kijów 2007.

${ }^{65}$ Wypędzeni ze Wschodu. Wspomnienia Polaków i Niemców, red. Hans Jürgen-Bömelburg, Olsztyn 2001. Ten rodzaj opracowania z perspektywy dziecięcego spojrzenia pozwala nabierać dystansu wobec tragicznych wydarzeń, z drugiej zaś strony bezlitośnie je przybliża; L. Karłowicz, Ciernista droga. Życie i działalność O. Martyniana Darzyckiego OFM więźnia Kołymy, Kalwaria Zebrzydowska 1997; H. Warachim OFMCap, Włóczęga Boży. O. Serafin Kaszuba - Kapucyn. Apostoł Wołynia, Kazachstanu i Syberii, Kraków 1991; H. M. Wilk OFMCap, „Ty nie zginiesz”, Lublin 2001.

${ }^{66}$ Zobacz przypisy: 13, 14 i 15.

${ }^{67}$ Świadectwo Kościoła katolickiego w systemie totalitarnym Europy Środkowo-Wschodniej. Księga Kongresu Teologicznego Europy Środkowo-Wschodniej KUL 11-15 sierpnia 1991 r., red. J. Nagórny, Lublin 1994; Zbrodnie NKWD na obszarze województw wschodnich Rzeczypospolitej Polskiej. Materiaty I Międzynarodowej Konferencji Naukowej. Koszalin 14 grudnia 1995, red. B. Polak, Koszalin 1995; Polacy i Kościót rzymskokatolicki na Wotyniu w latach 1918-1997. Materiały $z$ międzynarodowej sesji naukowej zorganizowanej w Lublinie $w$ dniach 9-10 grudnia 1997 r., red. L. Popek, Lublin 1999; Represje wobec duchowieństwa Kościołów chrześcijańskich w okresie stalinowskim w krajach bylego bloku wschodniego, pod red. Ks. J. Myszora i A. Dziurka, Katowice 2004; Powiat przemyski w latach 1944-1956, red. K. Kaczmarski i M. Krzysztofiński, PrzemyślRzeszów 2006; Powiat sanocki w latach 1944-1956, red. K. Kaczmarski i A. Romaniak, RzeszówSanok 2007. 
lecia posługi pasterskiej w Kościele rzeszowskim, red. E. Białogłowski i in., t. 1, Rzeszów 2007, s. 561-576; Marceli Wysokiński SJ (1884-1959) - Świadek Wiary i Nadziei na Podolu, „Teka Komisji Historycznej”, 3 (2006) s. 187-199; Kościót katolicki w obwodzie kamieniecko-podolskim w 1945 r., w: Historia świadectwem czasów. Księdzu Markowi Tomaszowi Zahajkiewiczowi, red. W. Bielak, S. Tylus, Lublin 2006, s. 471-482; Biskup nominat dla Kijowa i Ukraińskiej SRR - Wojciech Olszowski (1916-1972), „Studia Leopoliensia”, 2007 (w druku)]; L. Popek [Diecezja Łucka, w: Życie religijne w Polsce pod okupacja 1939-1945. Metropolie wileńska i lwowska, zakony, red. Z. Zieliński, Katowice 1992, s. 497-502; Świqtynie Wolynia, t. 1, Lublin 1997]; L. J. Draus, J. Musiał, A. Hlebowicz [Kościót odrodzony. Katolicyzm w państwie sowieckim 1944-1992, Gdańsk 1993; Kościót w niewoli. Kościót rzymskokatolicki na Biatorusi i Ukrainie po II wojnie światowej, Warszawa 1991; Diecezja tucka - od zniewolenia po zmartwychwstanie (1944-1989), w: Polacy i Kościót rzymskokatolicki na Wotyniu w latach 19181997. Materiaty z międzynarodowej sesji naukowej zorganizowanej w Lublinie $w$ dniach 9-10 grudnia 1997 r., red. L. Popek, Lublin 1999, s. 63-74; Martyrion Wschodu, „Ethos” 14(2001) nr 1-2, s. 139-150; Polskie duchowieństwo katolickie na Białorusi i Ukrainie po II wojnie światowej, w: Polacy w Kościele katolickim $w$ ZSRR, red. E. Walewander, Lublin 1991, s. 175-185].

W zakresie biografistyki podstawowymi opracowaniami dotyczącymi duchowieństwa represjonowanego są: podczas okupacji niemieckiej - W. Jacewicza i J. Wosia [Martyrologium polskiego duchowieństwa rzymskokatolickiego pod okupacja hitlerowska w latach 1939-1945, z. 1-5, Warszawa 1977-1981]; za wschodnią granica - Stownik biograficzny duchowieństwa metropolii lwowskiej obrzadku łacińskiego ofiar II wojny światowej 1939-1945, red. J. Krętosz, M. Pawłowiczowa, Opole 2007, ks. R. Dzwonkowskiego [Leksykon duchowieństwa polskiego represjonowanego w ZSRS w latach 1939-1988, Lublin 2003]; T. Madały [Polscy księza katoliccy w więzieniach i łagrach sowieckich od 1918 r., Lublin 1996]; w PRL - ks. J. Myszora [Leksykon duchowieństwa represjonowanego w PRL w latach 1944-1989. Pomordowani - więzieni - wygnani, red. J. Myszor, t. 1-2, Warszawa 2001-2002]; w diecezji przemyskiej - Z. K. Wójcika [Udział księży diecezji przemyskiej obrzqdku łacińskiego $w$ działalności podziemia antykomunistycznego w latach 1944-1956. Przyczyny - fakty - represje, ,Śląskie Studia HistorycznoTeologiczne" 1(2003), 217-234; Bandyci w sutannach. Księża diecezji przemyskiej ob. łac. przed Wojskowym Sadem Rejonowym w Rzeszowie na przetomie lat 1949-1950, w: Historia. Archiwistyka. Ludzie. Księga Pamiatkowa w pięćdziesiata rocznice powołania Archiwum Państwowego w Rzeszowie, red. J. Basta, G. Zamojski, Warszawa 2000, s. 153-170]; R. Szczęch [Aparat bezpieczeństwa wobec księży Kościoła rzymskokatolickiego diecezji przemyskiej w latach 1944-1954, Przemyśl 2006].

Cennym uzupełnieniem naszej wiedzy nt. stosunków Państwo - Kościół są prace: J. Żaryna [Dzieje Kościoła katolickiego w Polsce (1944-1989), Warszawa 2003; Kościół a władza w Polsce (1945-1950), Warszawa 1997; Aparat bezpieczeństwa w walce z duchowieństwem katolickim 1945-1949. (Zarys problemu), w: Skryte oblicze systemu komunistycznego. U źródet zła, red. R. Bäcker, P. Hübner, 
Warszawa 1997, s. 91-120]; A. Dudka [Państwo i Kościót w Polsce 1945-1970, Kraków 1995; A. Dudek i R. Gryz, Komuniści i Kościót w Polsce (1944-1989), Kraków 2003]; ks. Z. Zielińskiego [Kościót katolicki w Polsce 1944-2002, Radom 2003]; H. Dominiczaka [Organy bezpieczeństwa PRL w walce z Kościolem katolickim 1944-1990 w świetle dokumentów MSW, Warszawa 2000]; B. Fijałkowskiej [Partia wobec religii i Kościoła w PRL, t. 1: 1944-1955, Olsztyn 1999].

Biorąc pod uwage dotychczasowe opracowania na temat metropolii lwowskiej, nie możemy zapominać o czasopismach ${ }^{68}$ na łamach, których utrwalano dzieje duszpasterzy i wiernych podległych represjom, szczególnie z uwzględnieniem lokalnych uwarunkowań ${ }^{69}$.

W świetle nowych źródeł i najnowszych publikacji, które uwzględniają prace zbiorowe dotyczące trudnego sąsiedztwa polsko-ukraińskiego ${ }^{70}$ ciekawie zapowiadają się monografie dotyczące dziejów dwóch z pośród trzech diecezji metropolii lwowskiej. Pierwszą monografię - rozprawę habilitacyjną - dotyczącą diecezji łuckiej Kościót katolicki na Wolyniu w warunkach okupacji 1939-1945 przygotowuje M. Dębowska - adiunkt w Instytucie Archiwów Bibliotek i Muzeów Kościelnych KUL, drugą - rozprawę doktorską - Funkcjonowanie diecezji przemyskiej obrzqdku łacińskiego w warunkach okupacji niemieckiej i sowieckiej przygotowuje ks. S. Zych asystent w Instytucie Badań nad Polonią i Duszpasterstwem Polonijnym KUL.

Z ilości publikacji i liczby autorów, którzy zajmują się powyższą problematyką można wnioskować, że stan badań nad dziejami metropolii jest imponujący. Ciagle jednak brak syntetyzującej monografii omawiającej skalę represji wobec Metropolii Lwowskiej w latach 1939-1950. Dotychczasowe opracowania maja charakter przyczynkarski tak do miejsca (większość diec. przemyska) jak i czasu (1939-1945), który opisują. Nie uwzględniają też lokalnych uwarunkowań, które nie pozostawały bez wpływu zarówno na poszczególnych duszpasterzy jak i powierzonych ich opiece wiernych.

Przez wieki Polacy i Ukraińcy żyli w bezpośredniej bliskości. Przenikając się, wytworzyli wspólne dziedzictwo kulturowe, które w imię szeroko rozumianego

${ }^{68}$ Problematyka polsko-ukraińska, dawna i współczesna, prezentowana była i jest w czasopismach: Kronika Diecezji Przemyskiej, Przemyśl 1901-1992, jej kontynuacją jest Kronika Archidiecezji Przemyskiej, Mówiq Wieki, Sprawy Narodowościowe, Zeszyty Historyczne, Kultura (paryska), Przeglad Wschodni, Studia Rzeszowskie, Nasza Przeszłość, Kraków 1949 $\rightarrow$, Przeglad Polonijny, Więż, Rota, Forum Polonijne, Resovia Sacra, Rzeszów 1994 $\rightarrow$; Zeszyty Historyczne WiN-u, Przemyskie Zapiski Historyczne, Ziemia Drohobycka, Wrocław $1991 \rightarrow \mathrm{i}$ inne.

${ }^{69}$ W. Basak, Działania komunistów wobec Kościoła rzymsko i greckokatolickiego na terenie potudniowo wschodniej rzeszowszczyzny w latach 1944-1997, „Resovia Sacra”, 13 (2006) s. 223 -232 .

${ }^{70}$ Ogromnie przydatne przy badaniach położenia ludności polskiej na ziemiach ukraińskich są prace zbiorowe: Polacy i Ukraińcy dawniej i dziś, Kraków 2000, red. B. Grot; Stosunki polsko-ukraińskie w latach 1939-2004, red. B. Grot, Warszawa 2004; Między sobq. Szkice historyczne polskoukraińskie, Lublin 2000; Polska i Ukraina po II wojnie światowej, Rzeszów 1998, red. W. Bonusiak, dziewięciotomowe wydawnictwo Polska-Ukraina: Pytania, Warszawa 1998-2000; Polska-Ukraina. 1000 lat sqsiedztwa, Przemyśl 1990; Ukraina. Teraźniejszość i przeszłość, red. M. Karaś, A. Podraza, Kraków 1970. 
dobra ZSRR musiało być złożone na ołtarzu polityki radzieckiej. Dziś przy zachowaniu szacunku i tolerancji wobec tożsamości narodowej, potrzeba zweryfikować uproszczone sądy, wyzbyć się narosłych uprzedzeń. Czas najwyższy, żeby ukazać dzieje metropolii, pracujących w niej duszpasterzy i należących do niej wiernych bez koniunkturalnych zafałszowań, nawarstwionych stereotypów. Wszystko po to, aby pomimo obfitej daniny krwi, może przez łzy dostrzec prawdę o sobie. Prawdę, która w dalszym ciągu oczekuje na badaczy w archiwach rosyjskich, ukraińskich i polskich.

\section{DER REPRESSIONSAPPARAT GEGEN DIE KATHOLISCHE KIRCHE DER METROPOLIE LEMBERG LATEINISCHEN RITUS' IN DEN JAHREN 1939-1950. ZUM STAND DER FORSCHUNGEN}

\section{Zusammenfassung}

Die verhältnismäßig kurze Etappe in der Geschichte der katholischen Kirche, die die Jahre 1939-1950 umfasst, gehörte zu den besonders dramatischen in der polnischen Kirchengeschichte. Ganz besonders litt darunter die Lemberger Mertropolie lateinischen Ritus'. Zu ihr gehörten die Archidiözese Lemberg (Lwów), die Diözese Przemyśl und die Diözese Luzk (Łuck).

Nach dem Angriff Deutschlands gegen die UdSSR wurde Galizien, das östliche Kleinpolen, entgegen den Bestrebungen der Ukrainer, einen unabhängigen Staat zu gründen, dem Generalgouvernement angegliedert, und ein Teil von Wolhynien kam zum Reichskommissariat Ukraine. Die Quintessenz des Verhältnisses der Ukrainer zu den Polen in den Ostgebieten bildeten die massenhafte Abschlachtung Tausender von Polen in Wolhynien und im östlichen Kleinpolen. Heute fällt es schwer, wenigstens annähernd die Zahl der Polen zu bestimmen, die in diesen ukrainischen Mordaktionen umkamen. Verschiedene Autoren nennen unterschiedliche Opferzahlen. Es wird geschätzt, dass in den früheren polnischen Ostgebieten etwa 300.000 Polen umgekommen sind, davon 80.000100.000 allein in Wolhynien.

Nach Beendigung des 2. Weltkrieges, infolge der Abmachungen von Potsdam bis zum 16. August 1945, gehörte das Territorium der Metropolie Lemberg lateinischen Ritus', d.h. die zu den Wojewodschaften Wolhynien, Stanislau und Tarnopol sowie zu einem großen Teil zur Wojewodschaft Lemberg gehörenden ehemaligen polnischen Gebiete, nach der veränderten staatlichen Zugehörigkeit und den administrativen Veränderungen zu den Bezirken Wolhynien, Równe, Tarnopol, Stanislau (Iwanofrankowsk) und Lemberg. Hinsichtlich der kirchlichen Administration befand sich in den Grenzen der UdSSR ein Teil der Archidiözese Lemberg, die Diözese Luzk sowie ein Teil der Diözesen Przemyśl und Transkarpatien.

Die die Ostgebiete der Zweiten Republik Polen betreffende Problematik erhielt erst in den neunziger Jahren ihr „Bürgerrecht” in allen möglichen Publikationen. Vereinzelte Versuche waren schon vorher, vor allem in Emigrantenkreisen, unternommen worden. Zu Beginn der achtziger Jahre erweiterte sich der Kreis derer, die diese Problematik erforschten, um Z. Fijałkowski und auch B. Kumor und Z. Obertyński.

Die Historiographie zur Geschichte der Metropolie Lemberg in dieser Zeit eröffnete 1982 eine Publikation unter dem Titel „Das religiöse Leben in Polen unter der Okkupation 1939-1945. Die 
Metropolien Wilna und Lemberg sowie die Orden". Wie der Herausgeber im Vorwort selbst betonte, war dieses Buch als eine Einladung zur Diskussion gedacht, und in der Praxis stellte es einen gut im Kontext verankerten Ausgangspunkt für weitere Forschungen zur Geschichte der Kirche dar. Aufgrund der Zeit ihrer Entstehung warfen jedoch die Zensurbehörden einen Schatten auf diese Arbeit.

Die ersten Versuche einer „Registrierung der Kriegsschäden” wurden auf Initiative der Krakauer Metroplitankurie unmittelbar nach dem Ende des 2. Weltkrieges, noch im Juli 1945, unternommen. Damals wurden alle Gemeindepfarrer und Pfarradministratoren verpflichtet, zu diesem Zweck entsprechende Fragebögen auszufüllen und bis Ende August 1945 einzuschicken. Diese Tätigkeit wurde von Pater Wł. Szołdrski geleitet, einem Redemptoristen.

Auf diese Form einer Dokumentierung der Situation der katholischen Kirche und ihrer Verluste in den Jahren 1939-1951 wurde dreißig Jahre später auf Bitten des Instituts für Historische Geographie der Kirche in Polen an der Katholischen Universität Lublin noch einmal zurückgegegriffen. Die Ergebnisse dieser Erhebungen präsentierte Pater J. Rąb in Form eines Typoskripts unter dem Titel „Die Pfarreien der Diözese Przemyśl in den Jahren 1939-1951”. Einen weiteren Versuch, sich mit dieser besonderen Herausforderung zu messen, bildete die Arbeit von Wł. Piętowski „Die polnischukrainischen Beziehungen nach Ausbruch des 2. Weltkrieges. Ein Abriss" (Czarna bei Łańcut, 1988). Ähnlich wie die vorigen Arbeiten konnte auch diese nicht veröffentlicht werden. Im Druck erschien lediglich eine von J. Draus und J. Musiał herausgegebene Publikation über die Skala des Einflusses von 35 Ordensgemeinschaften.

Gegenwärtig verfügen wir über umfangreiche Kenntnisse, was die Geschicke des römisch-katholischen Klerus und der Gläubigen in den einzelnen Diözesen, Dekanaten und Wojewodschaften der Zweiten Republik Polen sowie in den jeweiligen sowjetischen Bezirken, Regionen und Pfarreien betrifft. Dieses Wissen ist in Bildbänden, veröffentlichten Dokumenten, Tagebüchern und Memoiren, Korrespondenzen sowie in zahlreichen Artikeln und Arbeiten zugänglich, die das Resultat wissenschaftlicher Konferenzen darstellen. Ihren Beitrag zur Beschäftigung mit dieser Geschichte leisten Pater J. Wółczański, Bischof W. Urban, Pater T. Śliwa, Pater H. Borcy, Pater R. Dwonkowski, L. Popek, L. J. Draus, J. Musiał und A. Hlebowicz.

Grundlegend auf dem Gebiet der Biographistik, die die Repressionen gegen den Klerus betreffen, gehören die Arbeiten von W. Jacewicz und J. Woś (Repressionen während der deutschen Okkupation), Pater R. Dzwonkowski und T. Madała (hinter der Ostgrenze), Pater J. Myszor (in der Polnischen Volksrepublik), Z. K. Wójcik und R. Szczęch (in der Diözese Przemyśl). Wertvolle Ergänzungen unserer Kenntnisse über die Beziehungen von Staat und Kirche bieten die Arbeiten von Żaryn., A. Dudek, Pater Z. Zieliński, H. Dominiczak und B. Fijałkowski.

Aus der Menge der Publikationen und der Anzahl der Autoren, die sich mit dieser Problematik befassen, kann geschlussfolgert werden, dass der Forschungsstand zur Geschichte dieser Metropolie imponierend ist. Aber es fehlt immer noch an einer monographischen Synthese, die das Ausmaß der Repressionen gegen die Metropolie Lemberg in den Jahren 1939-1950 zusammenfassend behandeln würde. Die bisherigen Arbeiten stellen eher Einzelbeiträge dar, sowohl was die Orte (vorwiegend in der Diözese Przemyśl ) als auch die Zeit (1939-1945) betrifft, die sie schildern. Auch werden die jeweiligen örtlichen Bedingungen nicht berücksichtigt, die sowohl auf die einzelnen Seelsorger als auch die ihrer Obhut anvertrauten Gläubigen nicht ohne Einfluss geblieben sind.

Aus dem Polnischen übersetzt von Herbert Ulrich 